\title{
COMPARATIVE PHARMAKOGNOSTICAL STUDY OF ROOTS OF ROSA MAJALIS HERRM. AND ROSA CANINA L.
}

\author{
Tetiana Oproshanska, Olga Khvorost, Kateryna Skrebtsova, Konradas Vitkevicius
}

The aim is to conduct a comparative pharmacognostical study of the series of roots of Rosa (R.) majalis Herrm. and Rosa $(R$.) canina L. with the establishment of diagnostic features of morphological and anatomical structure and boundary limits of numerical indicators of raw materials.

Materials and methods. The fresh and dry raw materials were used to study the macroscopic microscopic features by microscope Delta optical BioLight 300 (Poland). Determination of total polyphenols was performed by spectrophotometry (on a spectrophotometer Optizen POP (Korea)) and HPLC (chromatograph an Agilent 12003 D LC System Technologies (USA)).

Results. The morphological (nature of the surface (periderm) and fracture) and anatomical (color of cell walls and their cavities; location of the sclerenchyma; the presence of a crystalline coating of the sclerenchyma at the root of $R$. canina; of various elements of the remains of the tetraarchic conducting bundle in the center of the root) diagnostical features of roots of $R$. majalis and $R$. Canina were established.

Comparing the numerical values of loss on drying (not more than $10 \%$ ), total ash (not more than $5 \%$ ), extractable matter (not less than $9 \%$ ) and the quantitative content of total polyphenols (not less than $4 \%$ ) it was determined that both types of raw materials according to these indicators are almost indistinguishable.

Conclusions. Loss on drying, total ash, extractable matter and content of total polyphenols of the root of $R$. majalis and $R$. canina do not have significant differences, that is why the root of both plant species can be used as medicinal plant raw materials such as "Rose root". The obtained data will be used in further research when creating methods of quality control of plant raw materials and phytomedicines

Keywords: root, Rosa, diagnostical features, morphological and anatomical structure, numerical indicators

\section{How to cite:}

Oproshanska, T., Khvorost, O., Skrebtsova, K., Vitkevicius K. (2021). Comparative pharmakognostical study of roots of Rosa Majalis Herrm. and Rosa Canina L. ScienceRise: Pharmaceutical Science, 5 (33), 71-78. doi: http://doi.org/10.15587/2519-4852.2021.243525

(C) The Author(s) 2021

This is an open access article under the Creative Commons CC BY license hydrate

\section{Introduction}

The genus of Rose belongs to the family Rosaceae and includes from 140 to 400 species that grow in the temperate and subtropical zone of the northern hemisphere [1-3]. The most species of the genus are cultivated (Rosa (R.) majalis Herrm., R. canina L., $R$. alba L., $R$. rugosa Thunb., $R$. centifolia L. etc.) [4]. Plants of the genus are widely used in medicine, cooking and horticulture. Fruits of different species of the genus of Rose are used in medicine as a source of vitamin $\mathrm{C}$, the content of which in the raw material ranges from $1 \%$ (R. canina) [5] to $17 \%$ in the fruits of $R$. rugosa. The fruits also contain organic acids, flavonoids, catechins, minerals, pectin ( $R$. majalis, $R$. canina) [6-8], fatty acids ( $R$. canina, $R$. rugosa) [7], carotenoids ( $R$. canina, $R$. corymbigera Borkh., $R$. nisami Sosn., $R$. teberdensis Chrshan.) [9], anthocyanins (R. spinosissima L., $R$. hraciana Tamam.) [2]. The main active ingredient of fruits are vitamin $\mathrm{C}$ and carotenoids [6]. The flowers of such species of the genus of Rosa as R. damascene Mill., R. gallica L., R. moschata Herrm., and $R$. centifolia are sources of essential oil [10].

According to the monograph "Rosa fruit" ${ }^{\mathrm{N}}$ " of State Pharmacopoeia of Ukraine (2.1) [11] as a plant raw material can be used fruit of $R$. rugosa, $R$. majalis, $R$. acicularis Lindl., $R$. davurica Pall., $R$. beggeriana Schrenk., R. fedischenkoana Regel., R. kokanika (Regel) Regel ex Juz., R. canina, R. corymdifera Borkh., R. micraniha Smith., R. psammophila Chrshan., R. tomentosa Smith., $R$. zangezura P. Jarosch and other species. The plant raw material «Rosa fruit» is used for preparing the multivitamin decoction, drugs "Holosas", "Carotolin", "Echinasal", "Phytodent" and "Rose hip syrup" which are used as choleretic, anti-inflammatory, wound healing agents $[6,12]$. The fruits are also part of the plant collection: "Immunophyte", "Detoxify", "Phytocystol", "Arfazetin”, vitamin collection № 2 and dietary supplements (Vitamin C with rose hips, C-500 With Rose Hips, Rose Hips), which exhibit vitamin, choleretic, diuretic, anti-inflammatory effects, improve metabolism and increase hormone synthesis [12].

Monographs on different plant species on Rose hips are available in the European Pharmacopoeia, the Pharmacopoeia of Japan, China, Korea, Belarus and Russia Federation.

Also, the Pharmacopoeia of China includes monographs "Flos Rosae Chinensis" and "Flos Rosae Ru- 
gosae" which use raw materials of $R$. chinensis Jacq. and $R$. rugosa accordingly.

Roots of $R$. majalis and $R$. canina are used in folk medicine in Ukraine, Belarus, Russia and other European countries. Decoction of the root of $R$. majalis has astringent and antiseptic effects and uses to treat dyspepsia, cystitis, hypertension and heart disease. Decoction of the root of $R$. canina is normalized metabolism, have antiinflammatory, choleretic, diuretic and bactericidal activity and uses to treat diseases of liver, kidney and heart, cystitis and hypertension [8]. The root of $R$. laevigata Michaux., R. multiflora Thunb. and Rose cymosa Tratt. which contains triterpenoids is used in China folk medicine [13-15]. There is a dietary supplement "Artofit" in the market of Ukraine one of the components of which is Rose roots. The supplement affects metabolism, promotes the dissolution and excretion of urate and oxalates, and it is recommended for use in gout, osteochondrosis, osteoarthritis, arthritis, radiculitis, uric acid diathesis and kidney stones [12]. The root of $R$. roxburghii Tratt. is used in Gui Zhou province of Chinese ethnomedicine as medicine for treatment various intestinal diseases [16].

Chinese clinics have made extensive use of the roots of Rose cymosa as a source of Chinese herb medicine Jinyinggen. Information about the chemical composition of the roots of Rose cymosa is insignificant and Chinese scientists have conducted a number of studies of ethanol extract. As a result, it was found that triterpenoids were dominated in the roots of Rose cymosa (found
27 compounds, including 2 undescribed triterpenoids). It was identified more than 10 substances with using thinlayer chromatography and high-performance liquid chromatography [17-19].

The roots of $R$. multiflora have been used as remedies for scabies, rheumatic arthralgia and stomatitis. It was studied an influence of root extract on atopic dermatitis [20].

The chemical composition of the roots of $R$. majalis and $R$. canina are little studied according to the literature. It is known that the roots contain triterpenoids, tannins, flavonoids, organic acids, ascorbic acid, amino acids, macro-and micronutrients [8]. Data on the morphology and anatomy and quantitative content of compounds are absent or different in different sources. Therefore, a comparative phytochemical characterization of the roots of $R$. majalis and $R$. canina as promising relatively new official species of medicinal plant raw materials are relevant.

The aim is to conduct a comparative pharmacognostical study of the series of roots of $R$. majalis and $R$. canina with the establishment of diagnostic features of morphological and anatomical structure and boundary limits of numerical indicators of raw materials.

\section{Research planning (methodology)}

The design of the experiment with a comparative phytochemical characterization of roots of $R$. majalis and R. canina included several steps (Fig. 1).

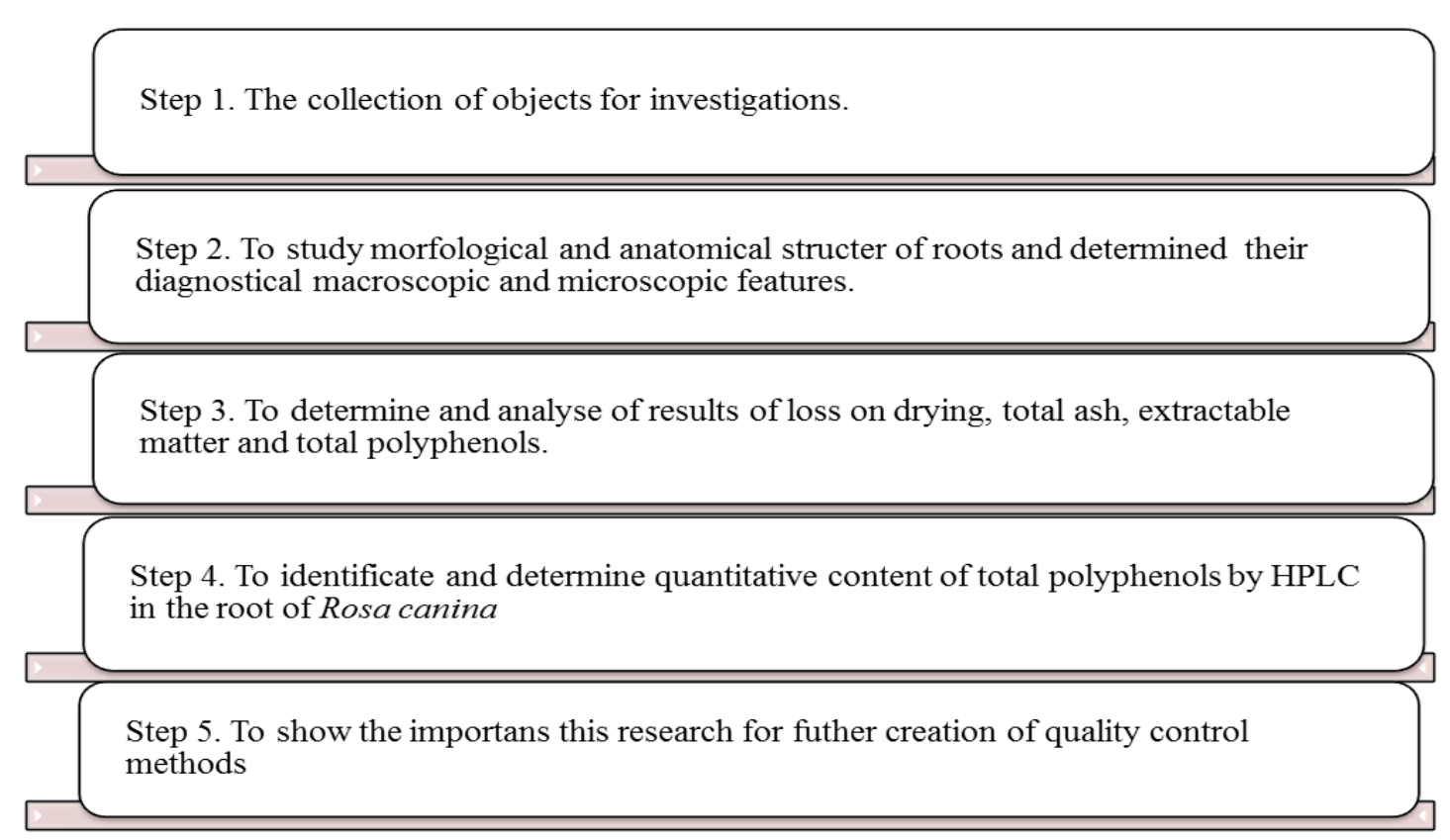

Fig. 1. Stage of the comparative pharmacognostical study of the series of roots of $R$. majalis and $R$. canina

\section{Materials and methods}

Roots of $R$. majalis and $R$. canina were harvested at the end of the growing season in 2019 in different regions of Ukraine (Table 1).

The study was carried out on the basis of the $\mathrm{Na}$ tional University of Pharmacy.

The harvested plant raw material was dried in a fruit and vegetable dryer (Scarlett SC-FD421004, China), at a temperature of $45-50^{\circ} \mathrm{C}$. Fresh and dry root fragments (up to $10 \mathrm{~cm}$ long) were used to study the anatomical structure. It was powdered on the grinder LZM-1 (Ukraine) plant raw materials (according to methods) for establishment numerical indicators and determine of total polyphenols.

The fresh and dry raw materials were used to study the macroscopic features, which were examined 
under a magnifying glass and microscope Delta optical BioLight 300 (Poland) at a magnification of 4 times to describe the fracture. The anatomical structure was studied from freshly harvested, fixed and dried raw materials.
Surface preparations and cross-sections were prepared according to generally accepted methods [21]. The microscopes Delta optical BioLight 300 with camera 2Mpx (Poland) were used for magnification at 100 and 400 times.

Date and regions of harvested of plant raw material

\begin{tabular}{|c|c|c|}
\hline Date & Region of harvested & Coordinates \\
\hline \multicolumn{3}{|c|}{ Root of R. majalis } \\
\hline 22.10 .2019 & Vinnytsia & $48.219646,28.668950$ \\
\hline 10.11 .2019 & Ternopil & $49.069444,26.160185$ \\
\hline 26.10 .2019 & Kharkiv & $49.910261,36.617300$ \\
\hline 31.10 .2019 & Lviv & $49.987377,24.071711$ \\
\hline 02.11 .2019 & Cherkasy & $48.815560,30.140253$ \\
\hline 01.11 .2019 & Poltava \\
\hline \multicolumn{3}{|c|}{ Root of R. canina } \\
\hline 22.10 .2019 & Vinnytsia \\
\hline 10.11 .2019 & Ternopil & $48.741328,34.484088$ \\
\hline 26.10 .2019 & Kharkiv & $49.069444,28.668950$ \\
\hline 31.10 .2019 & Lviv & $49.910261,36.617300$ \\
\hline 02.11 .2019 & Cherkasy & $49.987377,24.071711$ \\
\hline 01.11 .2019 & Poltava & $48.815560,30.140253$ \\
\hline
\end{tabular}

Quantitative determination of total polyphenols was performed by spectrophotometric method on a spectrophotometer Optizen POP (Korea) according to monograph 2.8.14. "Determination of tannins in herbal drugs" [22].

Loss on drying, total ash and extractable matter were determined according to monographs 2.2.32 "Loss on drying" [23], 2.4.16 "Total ash" [24] and 2.8.16 "Dry residue of extracts" [22].

The component composition and quantitative content of total polyphenols was studied by HPLC with using a chromatograph an Agilent 12003 D LC System Technologies (USA).

Test solution:

1. Flavonoids: to $1 \mathrm{~g}$ (exact portion) of the powdered raw material in a $250 \mathrm{ml}$ round bottomed flask add $50 \mathrm{ml}$ of a mixture of 40 volumes of water $R$ and 60 volumes of methanol $R$. Heat under a reflux condenser in a water-bath for $15 \mathrm{~min}$. Cool and filter through cotton into a $100 \mathrm{ml}$ volumetric flask. Rinse the cotton with a mixture of 40 volumes of water $R$ and 60 volumes of methanol $R$ and use this mixture of solvents to dilute the contents of the volumetric flask to exactly $100.0 \mathrm{ml}$. filter through a disposable membrane with a pore diameter of $0.45 \mu \mathrm{m}$.

2. Catechins: to $1 \mathrm{~g}$ (exact portion) of the powdered raw material in a $250 \mathrm{ml}$ round bottomed flask add $50 \mathrm{ml}$ of a mixture of 70 volumes of water $R$ and 30 volumes of methanol $R$. Heat under a reflux condenser in a water-bath for $30 \mathrm{~min}$. Cool and filter through cotton into a $100 \mathrm{ml}$ volumetric flask. Rinse the cotton with a mixture of 70 volumes of water $R$ and 30 volumes of methanol $R$ and use this mixture of solvents to dilute the contents of the volumetric flask to exactly $100.0 \mathrm{ml}$. filter through a disposable membrane with a pore diameter of $0.45 \mu \mathrm{m}$.

Column:

- size: $1=0.250 \mathrm{~m}, \mathrm{~d}=4.6 \mathrm{~mm}$;

- stationary phase: suitable octadecylsilyl silica gel for chromatography $R(5 \mu \mathrm{m})$.
Mobile phase:

- mobile phase A: $0,005 \mathrm{~N}$ solution of orthophosphoric acid $R$ for flavonoids and $0.1 \%$ trifluoroacetic acid $R, 5 \%$ acetonitrile $R$, water $R(\mathrm{pH}=2.08)$ for catechins (Table 2$)$;

- mobile phase B: acetonitrile $R$ for flavonoids and $0.1 \%$ trifluoroacetic acid $R$, acetonitrile $R$ for catechins (Table 2).

Table 2

Parameters of the gradient mode of elution of flavonoids and catechins

\begin{tabular}{|c|c|c|}
\hline Time (min) & $\begin{array}{c}\text { Mobile phase A } \\
\text { (per cent v/v) }\end{array}$ & $\begin{array}{c}\text { Mobile phase B } \\
\text { (per cent v/v) }\end{array}$ \\
\hline \multicolumn{3}{|c|}{ Flavonoids } \\
\hline 0 & 88 & 12 \\
\hline 30 & 75 & 25 \\
\hline 33 & 75 & 25 \\
\hline 38 & 70 & 30 \\
\hline 40 & 60 & 40 \\
\hline 41 & 20 & 80 \\
\hline 49 & 88 & 12 \\
\hline \multicolumn{3}{|c|}{} \\
\hline 0 & Catechins \\
\hline 8 & 0 & 100 \\
\hline 10 & 88 & 12 \\
\hline 15 & 88 & 12 \\
\hline 20 & 75 & 25 \\
\hline 25 & 75 & 25 \\
\hline 28 & 25 & 75 \\
\hline 29 & 25 & 75 \\
\hline
\end{tabular}

Flow rate: $0.8 \mathrm{ml} / \mathrm{min}$ for flavonoids and $0.1 \mathrm{ml} / \mathrm{min}$ for catechins.

Detection: spectrophotometer at $255 \mathrm{~nm}$ for flavonoids and $280 \mathrm{~nm}$ for catechins.

Injection: $10 \mu \mathrm{l}$ for flavonoids and $20 \mu \mathrm{l}$ for catechins.

Retention time: $60 \mathrm{~min}$ for flavonoids and $40 \mathrm{~min}$ for catechins. 


\section{Results}

Macroscopic features of raw materials: the roots of $R$. majalis (Fig. 2, a) and R. canina (Fig. 2, c) have the form of cut pieces of different lengths, twisted, cylindrical. The surface of the bark of the root of $R$. majalis is longitudinally wrinkled, the wrinkles are shallow, and the root of $R$. canina is deeply longitudinally wrinkled. The fracture of the root of $R$. majalis is granular, light brown or corporeal (Fig. 2, b), and the root of $R$. canina is fibrous and corporeal (Fig. 2,d). The cortex part is thin, the cambium does not stand out under a magnifying glass, the central part is radial. Anatomical features: structure of roots of $R$. majalis (Fig. 3, a) and $R$. canina (Fig. 3,d) is secondary beamless.

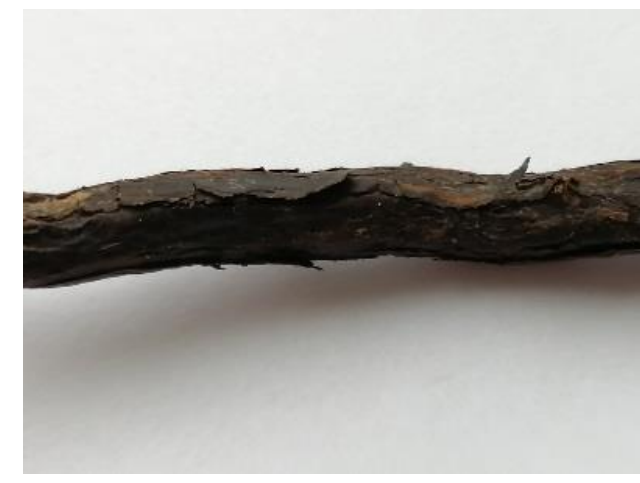

$a$

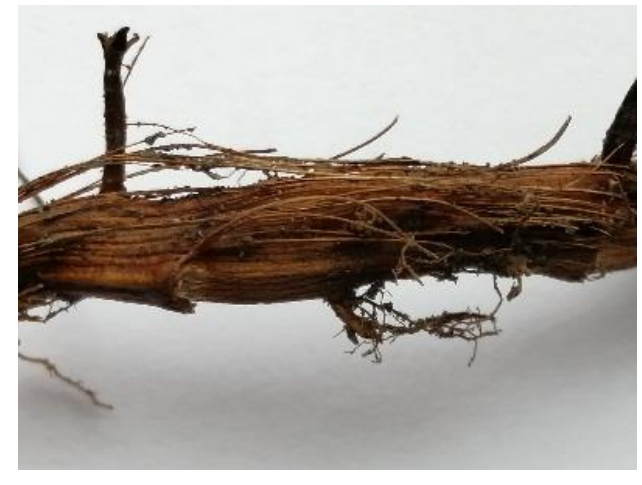

$c$

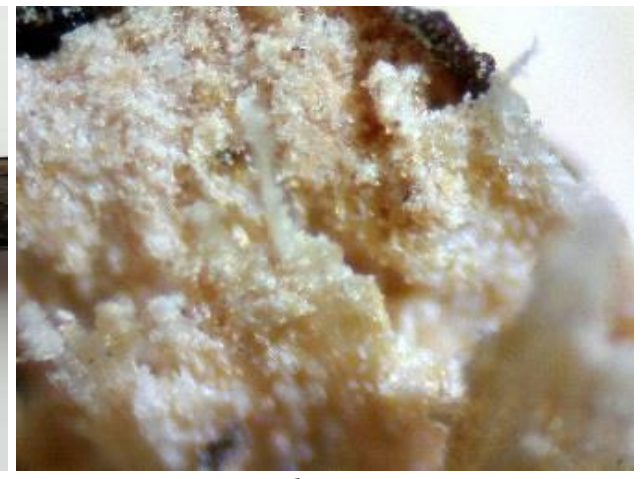

$b$

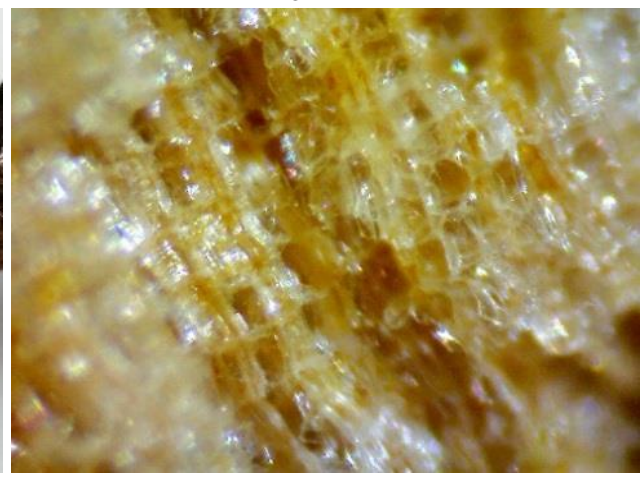

$d$

Fig. 2 Morphological features: $a$ - a form and surface of the root of $R$. majalis; $b$ - a fracture of the root of $R$. majalis; $c-$ a form and surface of the root of $R$. canina; $d-$ a fracture of the root of $R$. canina

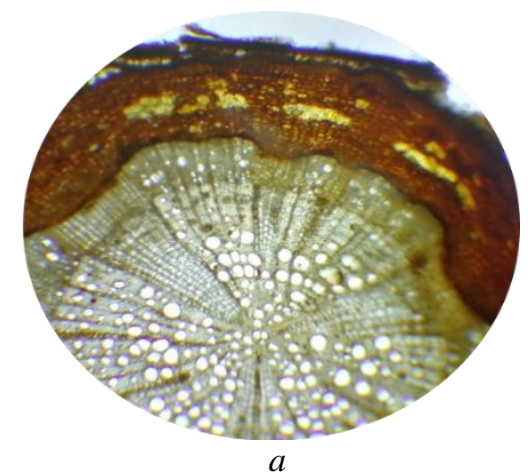

$a$

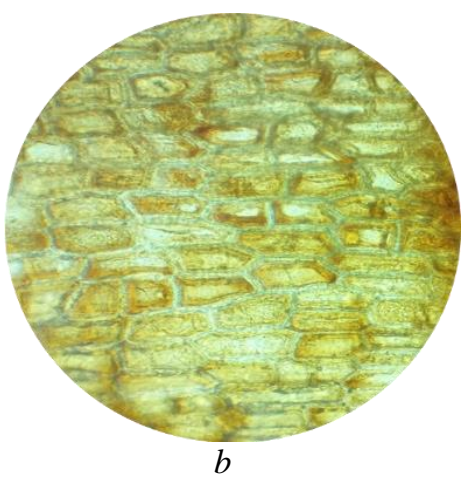

b

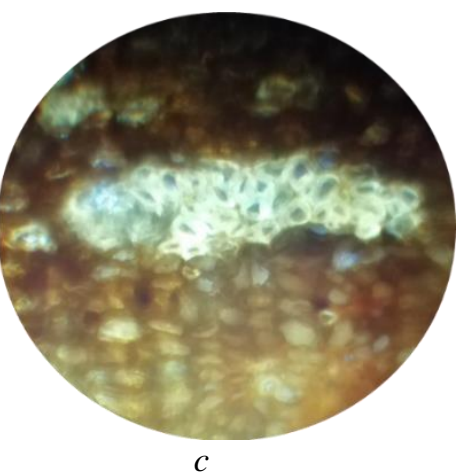

c
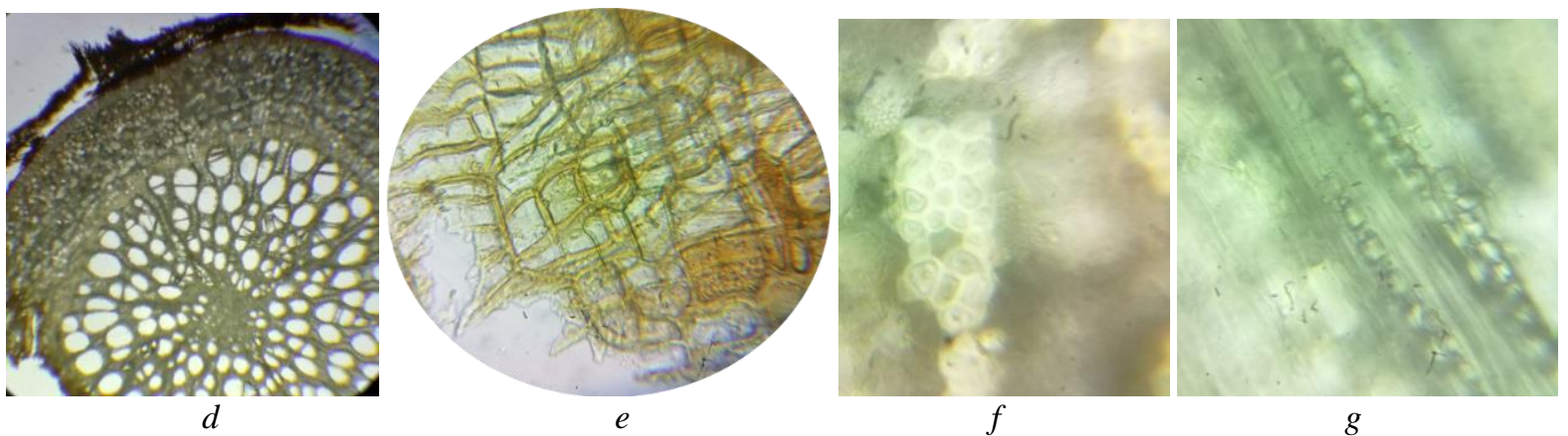

Fig. 3 Anatomical features: $a$ - the structure of the root of $R$. majalis; $b$-covering tissue of the root of $R$. majalis; $c$-bast fibers of the root of $R$. majalis; $d$ - the anatomical structure of the root of $R$. canina; $e$-covering tissue of the root of $R$. canina; $f$-bast fibers of the root of $R$. canina; $g$ - a crystalline coating of bast fibers of the root of $R$. canina 
Covering tissue is periderm. The external part of the periderm is the cork which consists of 4-5 (R. majalis) and 8 (R. canina) and more layers. The cork of 2 years old root may peel off. The cells of the cork are parenchymal, thick-walled; the cavities of the cells are dark brown in the roots of $R$. majalis (Fig. 3, $b$ ) and cell walls and some cavities are light brown in the roots of $R$. canina (Fig. 3,e).

Among the parenchymal cells of the cortex there are groups of cells (over 30 cells) of mechanical tissue sclerenchyma with yellow cell walls in the roots of R. majalis (Fig. 3,c) and lemon-yellow cell walls in the roots of $R$. canina (Fig. 3, f). The sclerenchyma are arranged in 2-3 circles in the roots of $R$. canina and the cross section shows that they have a crystalline coating, which is represented by single tetrahedral crystals of calcium oxalate (Fig. 3, $g$ ).
The vessels of the primary xylem of the remnant of the tetraarchic conducting bundle are at the center of root of $R$. majalis (Fig. 3, a), while the sclerenchyma which is part of the remains of the tetraarchic conducting bundle is in the center of root of R. canina (Fig. 3, d).

The secondary xylem is permeated with narrow single-row and wide two-three-row core rays. The leading xylem system is represented by large and small reticular vessels. Elements of conductive and mechanical tissue are dominated in the secondary xylem of the roots of $R$. majalis, and conductive tissue is dominated in the in the secondary xylem of roots of $R$. canina.

The results of determination of loss on drying, total ash, extractable matter and total polyphenols in different series of root of $R$. majalis and $R$. canina are given in Table 3.

Table 3

Determination of loss on drying, total ash, extractable matter and total polyphenols in the root of $R$. majalis and $R$. canina $(\mathrm{m}=5$, in terms of absolutely dry raw materials)

\begin{tabular}{|c|c|c|c|c|c|c|c|c|}
\hline $\begin{array}{c}\text { The place of } \\
\text { collection of } \\
\text { plant raw } \\
\text { material }\end{array}$ & \multicolumn{2}{|c|}{ Loss on drying (\%) } & \multicolumn{2}{|c|}{ Total ash (\%) } & \multicolumn{2}{c|}{ Extractable matter (\%) } & \multicolumn{2}{c|}{ Total polyphenols (\%) } \\
\cline { 2 - 9 } & $R$. majalis & $R$. canina & $R$. majalis & $R$. canina & $R$. majalis & $R$. canina & $R$. majalis & $R$. canina \\
\hline $\begin{array}{c}\text { Vinnytsia } \\
\text { region }\end{array}$ & $9.57 \pm 0.38$ & $9.88 \pm 0.40$ & $4.53 \pm 0.15$ & $4.62 \pm 0.15$ & $9.47 \pm 0.36$ & $10.12 \pm 0,37$ & $4.37 \pm 0,15$ & $4.50 \pm 0,15$ \\
\hline $\begin{array}{c}\text { Ternopil re- } \\
\text { gion }\end{array}$ & $9.59 \pm 0.38$ & $9.84 \pm 0.40$ & $4.57 \pm 0.15$ & $4.59 \pm 0.15$ & $9.50 \pm 0.36$ & $10.19 \pm 0,36$ & $4.39 \pm 0,15$ & $4.53 \pm 0,15$ \\
\hline $\begin{array}{c}\text { Kharkiv re- } \\
\text { gion }\end{array}$ & $9.43 \pm 0.39$ & $9.81 \pm 0.41$ & $4.50 \pm 0.15$ & $4.63 \pm 0.15$ & $9.44 \pm 0.36$ & $10.14 \pm 0,37$ & $4.40 \pm 0,15$ & $4.54 \pm 0,15$ \\
\hline Lviv region & $9.50 \pm 0.38$ & $9.91 \pm 0.41$ & $4.54 \pm 0.15$ & $4.58 \pm 0.14$ & $9.45 \pm 0.36$ & $10.10 \pm 0,37$ & $4.36 \pm 0,15$ & $4.48 \pm 0,16$ \\
\hline Poltava region & $9.34 \pm 0.37$ & $9.79 \pm 0.40$ & $4.53 \pm 0.14$ & $4.56 \pm 0.15$ & $9.47 \pm 0.36$ & $10.14 \pm 0,37$ & $4.37 \pm 0,15$ & $4.50 \pm 0,15$ \\
\hline $\begin{array}{c}\text { Cherkasy } \\
\text { region }\end{array}$ & $9.52 \pm 0.38$ & $9.80 \pm 0.40$ & $4.56 \pm 0.15$ & $4.56 \pm 0.15$ & $9.51 \pm 0.37$ & $10.16 \pm 0,37$ & $4.39 \pm 0,14$ & $4.52 \pm 0,15$ \\
\hline
\end{tabular}

As can be seen from Table 3 , the loss on drying for the root of $R$. majalis ranged from $9.34 \pm 0.37 \%$ (place of harvesting Poltava region) to $9.59 \pm 0.38 \%$ (place of harvesting Ternopil region). For the root of $R$. canina this indicator was slightly higher and ranged from $9.79 \pm 0.40 \%$ (place of harvesting Ternopil region) to $9.91 \pm 0.41 \%$ (place of harvesting Lviv region). Total ash for the roots of both species of Rose was almost the same and ranged from $4.50 \pm 0.15 \%$ in $R$. majalis (place of harvesting Kharkiv region) to $4.63 \pm 0.15 \%$ in $R$. canina (place of harvesting Kharkiv region). The highest content of extractable matter was found in the root of $R$. majalis, which was harvested in Cherkasy region $(9.51 \pm 0.37 \%)$ and in the root of $R$. canina from the place of harvesting in Ternopil region $(10.19 \pm 0.36 \%)$. At the same time with the lowest content of extractable matter of the root of $R$. majalis and $R$. canina were harvested in Kharkiv region and Lviv region respectively.

According to the literature, the plant raw material contains polyphenols, so the next step in a comprehensive study of raw materials was to determine the quantitative content of total polyphenols with using a spec- trophotometry as pharmacopoeial method of analysis (Table 3).

The content of total polyphenols in the root of $R$. canina is slightly higher than in the root of $R$. majalis. The following is observed: the highest content is inherent in raw materials of both types, which was harvested in the Kharkiv region, and the lowest - in the Lviv region. So, at the root of $R$. majalis this indicator ranged from $4.36 \pm 0.15$ to $4.40 \pm 0.15 \%$, and at the root of $R$. canina from $4.48 \pm 0.16 \%$ to $4.54 \pm 0.15 \%$.

As we can see the results determination of loss on drying, total ash, extractable matter and total polyphenols in the roots of $R$. majalis and $R$. canina, which were harvested in different regions of Ukraine are very similar. We can connect this fact only with the same conditions of harvested and drying, type of soil where plants grows and that it was at the same year.

Due to the fact, that the total polyphenols is slightly higher in $R$. canina, therefore the identification of them and their quantification by HPLC was performed in the root of $R$. canina (Kharkiv region) The results are shown in Table 4 and HPLC chromatograms in Fig. 4. 
HPLC study of polyphenols in the root of $R$. canina

\begin{tabular}{|c|c|c|}
\hline Name of compound & Retention time (min) & Quntitative content (\%) \\
\hline \multicolumn{3}{|c|}{ Flavonoids } \\
\hline Rutin & 15.81 & 0.06 \\
\hline Quercetin-3-D-glucoside & 19.53 & 0.01 \\
\hline Apigenin & 44.51 & 0.02 \\
\hline Sum of flavonoids & & 0.09 \\
\hline \multicolumn{3}{|c|}{ Catechins } \\
\hline Galic acid & 7.55 & 0.02 \\
\hline Gallocatechin & 9.67 & 0.58 \\
\hline Epigallocatechin & 12.01 & 2.83 \\
\hline Catechin & 12.92 & 0.95 \\
\hline Epicatechin & 15.07 & 0.41 \\
\hline Epicatechin gallate & 33.83 & 0.10 \\
\hline Sum of catechins & & 4.89 \\
\hline
\end{tabular}
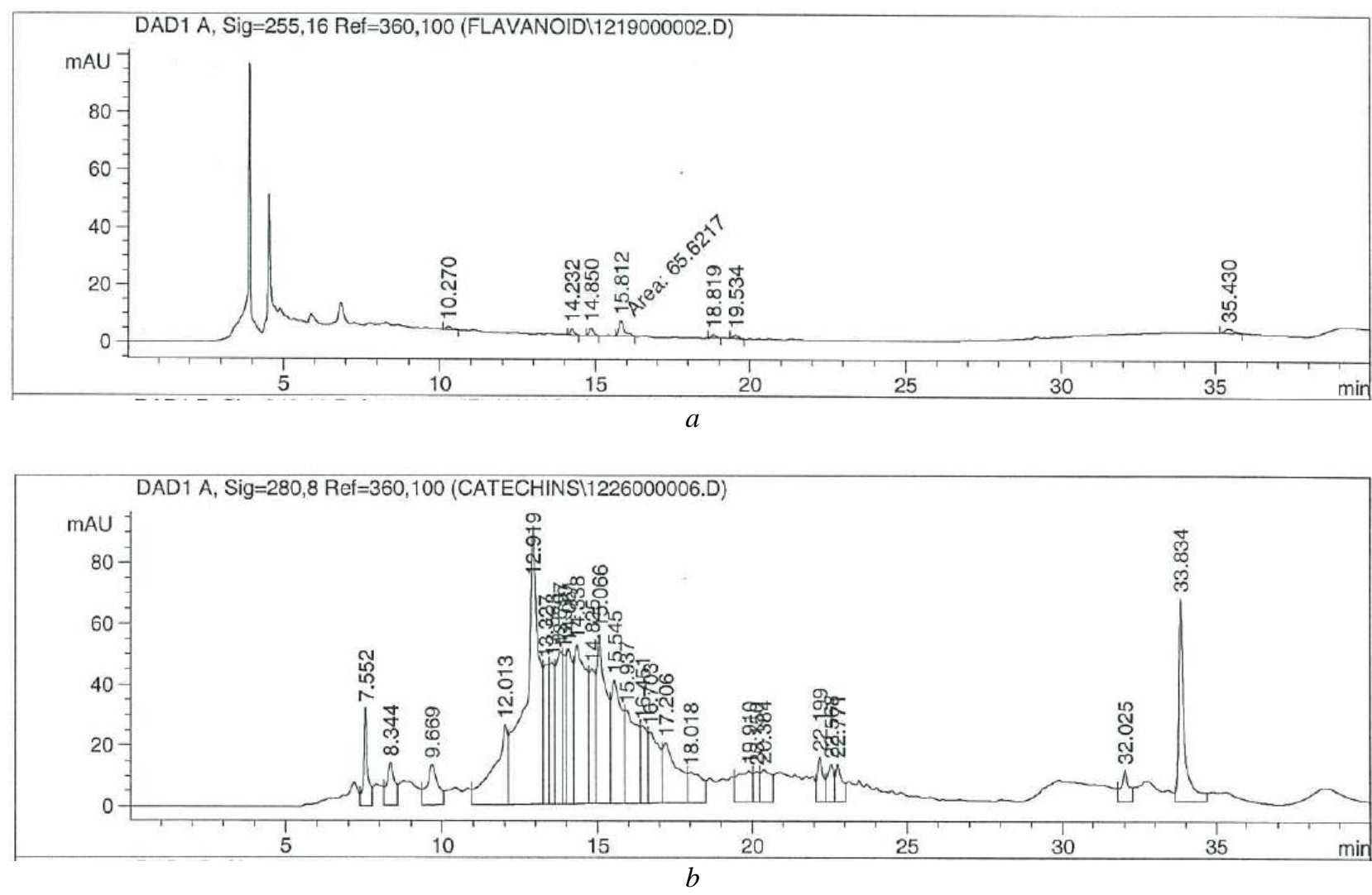

Fig. 4. HPLC chromatogram of polyphenols in the root of $R$. canina: $a$-flavonoids; $b$-catechins

It was identified and determined the quantitative content of three flavonoids in the root of $R$. canina: 2 glycosides (rutin and quercetin-3-D-glucoside) and 1 aglycone (apigenin). The quantitative content of flavonoids was dominated by rutin (2/3 of the total content of flavonoids). In addition, 6 compounds of catechin nature were identified in the raw material and their quantitative content was determined (the total content was $4.89 \%$ ). The root of $R$. canina contains the highest content of epigallocatechin (almost $3 \%$ of the total content of catechins) from identified catechins.

\section{Discussion of research results}

The definition of morphological and anatomical features of raw materials is important for the identification of medicinal plant raw materials. Description of these diagnostic features is a necessary section of monographs on plant raw materials. Roots of $R$. majalis and $R$. canina is little studied plant raw materials which are used in folk medicine. There is information about studying anatomical structure root of $R$. canina [25]. The comparative analysis of literature and the results are given in Table 5. 
Differences in the anatomical structure of the roots of $R$. canina

\begin{tabular}{|l|c|l|}
\hline \multicolumn{1}{|c|}{ Features } & Literature & \multicolumn{1}{c|}{ Obtained results } \\
\hline Covering tissue & name & name and describing cells \\
\hline Crystals & absent & single crystals forms a crystalline coating of sclerenhima \\
\hline Secondary xylem & present & the dominant tissue is indicated \\
\hline Primary xylem & present & the specified tissue which is located in the center (sclerenchyma). \\
\hline
\end{tabular}

According to Table 5 a distinctive feature of our results is the presence of a crystalline coating of the sclerenchyma. Also there are a detailed description cells of covering and conductive tissue and the dominant tissue of the secondary and primary xylem. In addition, a comparative morphological and anatomical study of roots of $R$. majalis and $R$. canina was carried out and diagnostic features were established.

Distinctive macroscopic features include the nature of the surface (periderm) (longitudinally wrinkled, the wrinkles are shallow in the root of $R$. majalis and deeply longitudinally wrinkled in the root of $R$. canina) is of the root and the nature of the fracture (granular in the root of $R$. majalis and fibrous in the root of R. canina).

Distinctive anatomical features of the roots of $R$. majalis and $R$. canina are:

- the color and position of the cell walls of cork and their cavities (colorless cell walls and dark brown cavities in the root of $R$. majalis and light brown cell walls and some cavities in the root of $R$. canina);

- color and location of cells of sclerenchyma: in $R$. majalis are yellow and arranged in one layer, in $R$. canina are lemon-yellow and arranged in 2-3 layers;

- the presence of a crystalline coating of sclerenchyma in the root of $R$. canina;

- prevalence in the xylem of elements of conductive and mechanical tissue in the root of $R$. majalis and conductive tissue in the root of $R$. canina;

- the presence of various elements of the remains of the tetraarchic conducting bundle in the center of the root: vessels of the primary xylem in $R$. majalis and sclerenchyma in $R$. canina.

According to pharmacopoeial requirements, the quality of raw materials is determined by numerical indicators, so the definition of their limits is important in the development of methods for quality control of raw materials.

Comparing the numerical values of loss on drying (not more than $10 \%$ ), total ash (not more than $5 \%$ ), extractable matter (not less than $9 \%$ ) and the quantitative content of total polyphenols (not less than $4 \%$ ) it was determined that both types of raw materials according to these indicators are almost indistinguishable. The result of HPLC shows that the root of $R$. canina contains almost $3 \%$ of epigallocatechin from of the total content of catechins, which can be used as marker for identification raw materials by thin-layer chromatography.

Study limitations. A limitation of the study could be considered the lack of identification of polyphenols and their quantification by HPLC of the root of $R$. majalis which makes it impossible to compare the qualitative composition and quantitative content of this group of compounds in two species of plant raw materials.
Apart from these it is necessary to continue determination content of loss on drying, total ash, extractable matter and the quantitative content of total polyphenols in more series of plant raw materials and bordered harvested regions and determined the dynamics of accumulation for several years.

Prospects for further research. Promising areas for further research are to continue studying of roots of $R$. majalis and $R$. canina as a relatively new type of official medicinal plant raw materials for expanding the raw material base, creating quality control methods of their standardization and developing of phytomedicines.

\section{Conclusions}

1. For the first time a comparative phytochemical characterization of roots of $R$. majalis and $R$. canina was carried out, their macro- and microscopic common and distinctive features were established and the numerical indicators of plant raw materials were determined.

2. It was establishment morphological diagnostical features of roots of $R$. majalis та $R$. canina: the nature of the surface (periderm) and fracture of root.

3. It was establishment anatomical diagnostical features of roots of $R$. majalis ta $R$. canina: color of cell walls and their cavities; location of the sclerenchyma; the presence of a crystalline coating of the sclerenchyma at the root of $R$. canina; of various elements of the remains of the tetraarchic conducting bundle in the center of the root.

4. Loss on drying, total ash, extractable matter and content of total polyphenols of the root of $R$. majalis and $R$. canina are almost indistinguishable, that is why the root of both plant species can be used as medicinal plant raw materials such as "Rose root".

5 . The obtained data will be used in further research when creating methods of quality control of plant raw materials "Rose root" and phytomedicines.

\section{Conflict of interest}

The authors declare that there are no conflicts of interests.

\section{Financing}

The work was carried as a part of a comprehensive research work of the National University of Pharmacy «Pharmacognostic research of medicinal plant raw materials and development of phytotherapeutic agents based on it» (state registration number 0114U000946).

\section{Acknowledgement}

We express our deep gratitude to the associate professor of the Botany Department of National University of Pharmacy Olha Filatova for the botanical determination of the plant raw materials which we studied. 


\section{References}

1. Vasileva, O. Iu. (2006). Osobennosti ontogeneza nekotorykh vidov roda Rosa (Rosaceae). Rastitelnye resursy, 42 (3), $25-37$.

2. Navruzov, A. R., Shamsizade, L. A. (2011). Antotsiany plodov dvukh vidov roda Rosa. Khimiia prirodnykh soedinenii, 1, 107.

3. The plant list. A working list of all plant species. Available at: http://www.theplantlist.org/tpl1.1/search?q=rosa

4. Kapelian, A. I. (2015). Sezonnii ritm razvitiia introdutsirovannykh vidov roda Rosa (Rosaceae) v parke botanicheskogo sada Bin Ran (g. Sankt-Peterburg). Rastitelnye resursy, 51 (3), 357-364.

5. Novruzov, A. R. (2014). Contents and dynamics of accumulation of the ascorbic acid in fruits of Rosa Canina L. Chemistry of Plant Raw Material, 3, 221-226. doi: http://doi.org/10.14258/jcprm.1403221

6. Sergunova, E. V., Sorokina, A. A. (2011). Issledovaniya po standartizacii plodov shipovnika. Pharmacy, 5, 12-15.

7. Crabowska, K., Janeczko, Z. (2012). Fatty acid composition of the monogalactosyldiacyl-glycerol fraction obtained from Rosa sp. And litizin. Khimiia prirodnykh soedinenii, 3, 416-418.

8. Oproshanska, T., Khvorost, O. (2021). Potentiometric determination of organic acids in the medicinal plant raw material. News of Pharmacy, 1 (101), 11-17. doi: http://doi.org/10.24959/nphj.21.42

9. Novruzov, A. R., SHamsizade, L. A. (2012). Karotinoidy plodov nekotorykh vidov Rosa. KHimiia prirodnykh soedinenii, $5,802$.

10. Honarvar, M., Javidnia, K., Khosh-Khui, M. (2011). Essential oil composition of fresh and dried flowers of Rosa moschata from Iran. Chemistry of Natural Compounds, 47 (5), 826-828. doi: http://doi.org/10.1007/s10600-011-0075-2

11. Derzhavna farmakopeia Ukrainy Dop. 1 (2.0). (2016). Kharkiv: DP «Naukovo-eksportnyi farmakopeinyi tsentr», 360.

12. Kompendium. Available at: https://compendium.com.ua/

13. Li, Y.-L., Dai, H.-N., Ma, G.-X., Zhang, W., Wu, T.-Y., Wang, Y.-Q. et. al. (2017). A new triterpenic acid from the roots of Rosa laevigata. Yao Xue Xue Bao, 52 (3), 425-429.

14. Jiang, H., Han, H., Man, W.-J., Hou, A.-J., Guo, X.-Y., Xing, X.-D. et. al. (2020). Ursane-type triterpenoids from the roots of Rosa multiflora with their anti-inflammatory activity. Journal of Asian Natural Products Research, 22 (2), 131-137. doi: http://doi.org/10.1080/10286020.2018.1541135

15. Dai, H.-N., Ma, G.-X., Zhou, J.-M., Zhong, X. Q., Zhou, Y.-L., Lv, G.-R. et. al. (2016). Triterpenoids from roots of Rosa laevigata. Zhongguo Zhong Yao Za Zhi, 41 (12), 2267-2272. doi: https://doi.org/10.4268/cjcmm20161216

16. Ma, Y., Wang, Y., Zhang, H., Sun, W., Li, Z., Zhang, F. et. al. (2020). Antimicrobial mechanism of strictinin isomers extracted from the root of Rosa roxburghii Tratt ( $\mathrm{Ci} \mathrm{Li}$ Gen). Journal of Ethnopharmacology, 250, 112498. doi: http://doi.org/10.1016/j.jep.2019.112498

17. Fan, X., Bai, L., Lin, L., Liao, D., Gong, Y., Liu, X. et. al. (2020). Studies on the chemical constituents and quality evaluation of Rosa cymosa Tratt. root. Journal of Separation Science, 43 (24), 4379-4389. doi: http://doi.org/10.1002/jssc.202000005

18. Ji, Y., Xia, X., Xu, X., Zhu, N. (2019). Three new triterpenoids with their bioactives from the roots of Rosa cymosa. Natural Product Research, 34 (20), 2931-2937. doi: http://doi.org/10.1080/14786419.2019.1599886

19. Huang, X.-Y., Ma, G.-X., Zhong, X.-Q., Zhou, Y.-L., Dai, H.-N., Wu, H.-F. et. al. (2014). Triterpene constituents from Rosa cymosa Tratt. Zhongguo Zhong Yao Za Zhi, 39 (23), 4637-4641.

20. Park, K. H., Jeong, M. S., Park, K. J., Choi, Y. W., Seo, S. J., Lee, M. W. (2014). Topical Application of Rosa multiflora Root Extract Improves Atopic Dermatitis-Like Skin Lesions Induced by Mite Antigen in NC/Nga Mice. Biological and Pharmaceutical Bulletin, 37 (1), 178-183. doi: http://doi.org/10.1248/bpb.b13-00619

21. Upton, R., Graff, A., Jolliffe, G., Länger, R., Williamson, E. (Eds.) (2011). American Herbal Pharmacopoeia: botanical pharmacognosy-microscopic characterization of botanical medicines. CRC Press, 800.

22. Derzhavna farmakopeia Ukrainy (2.0). (2015). Kharkiv: DP «Naukovo-eksportnyi farmakopeinyi tsentr».

23. Derzhavna farmakopeia Ukrainy Dop. 5 (2.0). (2021). Kharkiv: DP «Naukovo-eksportnyi farmakopeinyi tsentr».

24. European Pharmacopoeia. Available at: https://pheur.edqm.eu/home

25. Aliyev, B. M., Qabilov, M. Y., Aliyeva, I. F., Huseynova, S. A. (2019). Morphological and anatomical structure of Rosa canina L. Modern Science, 10-1, 25-28.

Received date 14.09.2021

Accepted date 21.10.2021

Published date 29.10.2021

Tetiana Oproshanska, $\mathrm{PhD}$, Assistant professor, Department of Management and Economics of pharmacy, National University of Pharmacy, Pushkinska str., 53, Kharkiv, Ukraine, 61002

Olga Khvorost, Doctor of Pharmaceutical Sciences, Professor, Department of Chemistry of Natural Compounds and Nutrition, National University of Pharmacy, Pushkinska str., 53, Kharkiv, Ukraine, 61002

Kateryna Skrebtsova, PhD, Assistant. Department of Chemistry of Natural Compounds and Nutrition, National University of Pharmacy, Pushkinska str., 53, Kharkiv, Ukraine, 61002

Konradas Vitkevicius, Doctor of Pharmacy, Professor, Department of Analytical and Toxicological Chemistry, Medical academy, Lithuanian University of Health Sciences, A. Mickeviciaus str., 9, Kaunas, Lithuania, LT44307

*Corresponding author: Tetiana Oproshanska, e-mail: arctium55@ukr.net 